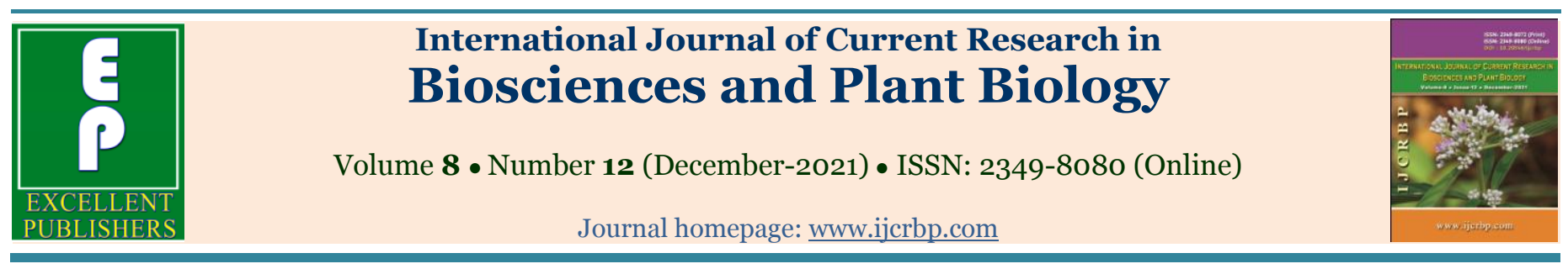

\title{
Phytochemical and antimicrobial studies on Hygrophila auriculata Schumach.
}

\author{
Suresh Kumar Jebamalai ${ }^{\mathbb{D} *}$, Nirmala Ramachandran ${ }^{\mathbb{D}}$, Venkatraman Arumugam
}

PG and Research Department of Botany, K.K. Government Arts College (Affiliated to Thiruvalluvar University, Vellore), Tiruvannamalai - 606 603, Tamil Nadu, India

*Corresponding author; e-mail: kanishkarmegam@gmail.com

\begin{tabular}{|c|c|}
\hline Article Info & Abstract \\
\hline $\begin{array}{l}\text { Keywords: } \\
\text { Antimicrobial activity } \\
\text { Hygrophila auriculata } \\
\text { Medicinal plants } \\
\text { Phytochemicals } \\
\text { Therapeutical } \\
\text { compounds }\end{array}$ & $\begin{array}{l}\text { In the present study, the medicinal plant Hygrophila auriculata was selected and the screening of the } \\
\text { qualitative and quantitative of phytochemicals. The phytochemical profiles were estimated through the } \\
\text { Gas chromatography-Mass spectrophotometer, which containing twenty compounds were listed out. } \\
\text { The antimicrobial activity of the methanolic extract of the entire plant was studied against five selected } \\
\text { bacterial and five selected fungal pathogens using well diffusion method. The results revealed that the } \\
\text { methanolic extract of Hygrophila auriculata possessed alkaloids, flavonoids, terpenoids and various } \\
\text { other phytochemicals. The extract showed antimicrobial activity against Aspergillus niger, Escherichia } \\
\text { coli, and Klebsiella pneumoniae with a range of } 8-16 \text { mm zone of diameter, This study gives a new } \\
\text { route to discovery of new drug for the control of microorganisms. }\end{array}$ \\
\hline
\end{tabular}

- Received: 3 November 2021 • Revised: 25 November 2021 • Accepted: 1 December 2021 • Published Online: 6 December 2021

\section{Introduction}

Herbal medicines have been used in medical practice for thousands of years and are recognized especially as a valuable and readily available healthcare resource. During the past decades, the contribution of herbal medicines and their preparations has attracted much interest in the pharmaceutical industry. However, most herbal medicines still need to be investigated scientifically, although the experience obtained from their traditional use over the years should not be ignored (Jacobson and Silverglade, 1999; Taylor et al., 2001).

Botanical drugs and dietary supplements may be obtained from a broader variety of plants than those normally present in the human diet. Botanicals or phytopharmaceuticals are very suitable for prophylactic use in order to prevent diseases and also to maintain our normal wellbeing. The screening and evaluation of medicinal plants is very dependent on the proper cultivation and collection of the plant materials followed by their extraction and isolation of the phytochemical entities to enable optimized bioactive compound production and subsequent therapeutic applications. This is very important for multicomponent drugs and their standardized extracts to ensure high quality and batch to-batch consistency (Mukherjee et al., 2006). The Indian subcontinent is the site of one of the oldest civilizations, and it has seen the development of many traditional health care systems.

In these modern days of sophisticated medicine and the new way of producing so many kinds of medicine, people, especially those from the cities, do 
not believe in the value and effectiveness of herbal plants that abound in this county as substitute to modern packaged or bottled pharmaceuticals.

Early people used almost 3,000 different plants as medicines. Man, from time immemorial for their extraordinary healing abilities, has used plants. Man's interest in herbal remedies has been revived recently with a new zeal. In spite of tremendous development in the field of synthetic drugs and antibiotics during the twentieth century, plants still constitute one of the major sources of drugs in modern as well as traditional medicine throughout the world. Even in modern medicine, 25 percent of the drugs are plant based. Medicinal plants have curative properties due to the presence of various complex chemical substances of different composition, which are found as secondary plant metabolites in one or more plants.

In India, medicinal plants have made a good contribution to the development of ancient India Materia Medica. One of the earliest treatises on Indian medicine, the charaksahlita (1000 B.C) records the use of over 340 drugs of vegetative origin. Medicinal plants have curative properties due to the presence of various complex chemical substances of different composition, which are found as secondary plant metabolites in one or more parts of these plants (Chandrasekar et al., 2010).

Due to the development of science and technology many new drugs of synthetic origin have come into existence. Even though the western medicine or drugs have immediate cure for the diseases caused by microorganisms, lot of side effects of long term duration are caused. These health hazards of synthetic medicine can be minimized by the use of herbal based medicine. Increasing number of diseases are resisting treatment due to the spread of drug resistance (Kumar, 1998).

In recent times, focus on plant research has increased all over the world and a large body of evidence has been collected to show immense potential of medicinal plants used in various traditional systems. In India the use of different parts of several medicinal plants to cure specific ailments has been in vogue from ancient time. Spreading and preserving the knowledge on medicinal plants and their uses has become important for human existence (Sofowora, 1984).
Hygrophila auriculata Schumach (Acanthaceae) grows throughout India. It is a wild herb commonly found in moist places on the banks of tanks, ditches and paddy fields throughout India. It is also found in many other countries like Malasia, Burma, Srilanka, Nepal, Pakisthan, and others (Sivarajan, 2017). It is a robust, erect annual herb. The stems are subquadrangular with thickened nodes. The leaves are oblanceolate, with a yellow spine in its axil, the flowers pale, purple blue, densely clustered in axils; distinctly 2-lipped, the upper 2-lobed and the lower 3-lobed. The fruits are oblong, linear capsules, 4-8 seeded (Sivarajan, 2017).

\section{Chemical composition}

The seeds contain large amounts of tenacious mucilage and potassium salts, due to which it possess diuretic properties. The seeds contain $23 \%$ of yellow semi-drying oil; they also contain diastase, lipase and protease. Extraction of Xylose and uronic acids from oil of seeds; lupenol, stigmasterol and straight-chain Hydro Carbons from lipid extract of plant, palmitic (7.2), stearic (0.8), oleic (11.9) and linoleic (80.1\%) acids from seed oil are reported (Joshi, 2000).

\section{Therapeutic use}

The roots, leaves and seeds have been used in Indian system of medicine as diuretics and also employed to cure jaundice, dropsy, rheumatism, anasarca and diseases of urinogenital tract. In Ayurvedic system of medicine, kokilaksha is a reputed remedy for arthritis. It is believed to promote strength and appetite; to cure oedema, ascites, thirst, bladder stones, eye diseases and dysentery. Decoction of its root is diuretic. Leaves and roots along with flowers of Stuea frondosa are useful for leucorrhoea. It is also known to be helpful in the cases of impotence, spermatorrhea and seminal debilities (Shanmugasundaram and Venkataraman, 2005).

Asteracantha known as Mokhla kanta, is one of the common wasteland weeds in India. White flowered variety of this plant had been observed in Chhattisgarh. The white flowered variety was preferred in Chhattisgarh as compared to the blue purple flowered variety. According to the traditional healers of the area, this variety is more effective 
not only in bleeding but also in healing the wound quickly. It is a source of many ayurvedic "Rasayana drugs" like "Kokilaksha" and "Spemen"; Unani drugs Talimkhana and Siddha drug "Neer mulli for treatment of various disorders (Vijaya Kumar, 2006).

It has been traditionally used for the treatment of inflammation and is a promising medicinal plant with great economic potential for its health-promoting properties (Singh and Handa,1995). The plant is cultivated throughout India and the leaves and roots of Hygrophila have diuretic properties. This plant has been traditionally used in the preparation of several Ayurvedic medicines such as Aviltholadi Bhasmam, Shula Vinashini Vatika and Panaviraladi Bhasmam for the treatment of disorders of liver, spleen, oedema (Patra et al., 2009).

Treatment of diabetic rats with aerial parts of Hygrophila auriculata extract showed significant reduction in blood glucose (Vijaya Kumar, 2006). It has been reported that the aqueous extract of aerial parts and root of Hygrophila auriculata were exhibited antinociceptive activity by central and peripheral mechanisms (Shanmugasundaram and Venkataraman, 2005).

\section{Phytochemical compounds}

Phytochemical methods provide the techniques for screening plants for various chemicals. The range and number of discrete molecular structure produced by plants is huge. For example, it has been estimated that there are now over 5500 known plant alkaloids and new ones are being discovered at fast rate. The chemical constituents of plants can be classified in many different ways. On the basis of biosynthetic origin and key functional groups, the following classes of compounds are generally present in plants:

- Phenolic compounds including phenolic acids, polyphenols, flavonoids, anthocyanins, flavanols, flavones, xanthon, quinone pigments etc.,

- Terpenoids such as monoterpene, essential oil, diterpenoids, and glaberellins, triterpenoids and steroids, saponins, carotenoids etc.,

- Lipids such as plants acids and triglycerids, phospholipids, glycolipids, polyacetylene, sulphur etc.
- Nitrogen compounds such as amino acids, alkaloids, indols, purins, pyrimidine and chlorophyll.

- Sugars- monosaccarides, oligosaccharides, etc.

- Macro molecules like nucleic acid, polysaccharide, and protein (Harborne, 1984).

In the present study, phytochemical compounds and the antimicrobial activity of the medicinal plant Hygrophila auriculata was carried out to explore the potential of the plant in controlling the microbes.

\section{Materials and methods}

\section{Collection of plant material}

The plant material Hygrophila auriculata Schumach. was collected from paddy fields in and around Appupattu village, Tiruvannamalai District on different days. The whole plants were collected and refrigerated for 2 to 4 days to keep them fresh.

\section{Preparation of plant extract}

The entire plants were dried in shadow. The dried plants were subjected to pulverization using a Sumit mixie, to get coarse powder. To $20 \mathrm{~g}$ of the coarse powder, $100 \mathrm{ml}$ of absolute alcohol (Analytical Reagent) was added. The mixture was kept soaking for $24 \mathrm{~h}$. Then the mixture was filtered using Whatmann no. 41 filter paper. The filtrate of the methanol extract was stored in air tight container in a refrigerator. The extract was used for phytochemical screening of compounds, and for antimicrobial studies (Kokate et al., 1995).

\section{Qualitative phytochemical studies}

Qualitative phytochemical analyses were done by using the procedures of standard methods (Singh and Handa, 1995). Alkaloids, carbohydrates, tannins and phenols, flavonoids, gums and mucilages, phytosterol, proteins, fixed oils and fats, volatile oil and saponins were qualitatively analyzed.

\section{Carbohydrates}

Methanol extracts $(300 \mathrm{mg}$ ) were dissolved separately in distilled water and filtered. The filtrate was boiled with Fehling's and with Benedict's solution. Formation of brick red precipitate in Fehling's and Benedict's solution is the positive result for reducing sugars and non-reducing sugars, respectively. 


\section{Test for carbohydrates}

A small quantity of extracts are dissolved separately in $5 \mathrm{ml}$ of distilled water and filtered. The filtrate is subjected to Molisch's test to detect the presence of carbohydrates.

Molisch's test: Filtrate was treated with $2-3$ drops of $1 \%$ alcoholic naphthol solution and $2 \mathrm{ml}$ of concentrated sulphuric acid is added along the sides of the test tube. The formation of purple colour showed the presence of carbohydrates.

\section{Alkaloids}

The extract was dissolved in dilute hydrochloric acid and filtered. The filtrate was tested carefully with various alkaloidal reagents such as Mayer, Dragendroff's, Hager's and Wagner's reagent superlatively. Appearance of cream, orange, brown, yellow and reddish brown precipitates in response to the above reagents respectively indicate the presence of alkaloids.

\section{Test for alkaloids}

A small portion of the extracts was stirred with a few drops of dilute hydrochloric acid and filtered and the filtrate was used for following tests.

Dragendorff's reagent: An orange precipitate obtained exhibits the presence of alkaloids.

Hager's reagent: A yellow precipitate formed it indicates the presence of alkaloids.

Wagner's reagent: A brown precipitate obtained shows the presence of alkaloids.

\section{Steroids}

Liberman Burchard test: 1g of the extract is dissolved in few drops of dry acetic acid. $3 \mathrm{ml}$ of acetic anhydride is added followed by few drops of conc. sulphuric acid. The formation of green colour provided the presence of sterols.

\section{Tannins and phenols}

Small quantities of methanol extracts were dissolved in water and to that ferric chloride solution $(5 \%)$ or gelatin solution $(1 \%)$ or lead acetate solution $(10 \%)$ was added. Appearance of blue colour with ferric chloride (or) precipitation with other reagent indicates the presence of tannins and phenols.

\section{Saponins}

One $\mathrm{ml}$ of each extract was dissolved separately in $20 \mathrm{ml}$ of water and shacked in graduated cylinder for 15 minutes. Formations of $1 \mathrm{~cm}$ layer of foam indicate the presence of saponins.

\section{Test for saponins}

The extracts are diluted with $20 \mathrm{ml}$ of distilled water and they are agitated in a graduated cylinder for 15 minutes. The formation of $1 \mathrm{~cm}$ layer of foam shows the presence of saponins.

\section{Fixed oils and fat}

All quantity of the various extracts is separately pressed between two filter papers. An oily stain obtained shows the presence of fixed oils. Few drops of $0.5 \mathrm{~N}$ alcoholic potassium hydroxide is added to a small quantity of various extracts along with a drop of phenolphthalein. The mixture is heated on a water bath for $1-2 \mathrm{~h}$. The formation of yellow coloration indicates the presence of fixed oils.

\section{Gums and mucilage}

About $10 \mathrm{ml}$ of extract was slowly added to $25 \mathrm{ml}$ of absolute alcohol under constant stirring. Precipitation indicates the presence of gums and mucilage.

\section{Proteins and free amino acids}

Small quantities of various extracts are dissolved in a few $\mathrm{ml}$ of water and treated with:

Ninhydrin reagent: A purple colouration obtained shows the presence of amino acids.

Biuret reagent: A violet colouration obtained shows the presence of proteins.

Millon's reagent: A yellow precipitate formed shows the presence of aromatic amino acids.

\section{Flavonoids}

The extract was mixed with few $\mathrm{ml}$ of alcohol. It was heated with magnesium and then conc. $\mathrm{HCl}$ was added under cooling. Appearance of pink colour indicates the 
presence of flavonoids. The extract with few $\mathrm{ml}$ of aqueous $\mathrm{NaOH}$, appearance of yellow colour and changes to colorless with $\mathrm{HCl}$ indicate the presence of flavonoids.

\section{Volatile oils}

For the detection of volatile oil, $50 \mathrm{~g}$ of powdered plant material were taken in a volatile oil estimation apparatus and subject it to hydro distillation. Collect the distillate in the graduated tube of the assembly in which the aqueous portion is automatically separated from the volatile oil. If it is present in the drug, it returned back to the distillation flask.

\section{Glycosides}

Another portion of the extract is hydrolysed with hydrochloric acid for few hours in a water bath and the hydrolysate is subjected to Legal's and Borntrager's tests to detect the presence of different glycosides.

Legal's test: To the hydrolysate, $1 \mathrm{ml}$ pyridine and few drops of sodium nitro prusside solution were added and then it was made alkaline with sodium hydroxide solution. The formation of purple colour indicates the presence of glycosides.

Borntrager's test: Hydrolysate was treated with chloroform and the chloroform layer was separated. To this equal quantity of dilute ammonia solution was added. The formation of yellow colour shows the presence of glycosides.

\section{Lipids}

Lipids may be detected without alteration by spraying plates with fluorescent dyes.

\section{Reducing sugar}

Estimation of reducing sugar was done by the method of Miller (1998). The amount of reducing sugar was calculated using standard curve prepared from glucose. The quantity of reducing sugar was expressed as $\mathrm{mg} / \mathrm{g}$ fresh weight of tissue.

\section{Terpenoids (Salkowski test)}

Presence of terpenoids in various fractions was determined according to Harbone (1973). 5ml
$(1 \mathrm{mg} / \mathrm{ml})$ of fraction was combined with few drops chloroform, and then $3 \mathrm{ml}$ of concentrated $\mathrm{H}_{2} \mathrm{SO}_{4}$. Change of reddish brown color revealed terpenoids.

\section{Quinone (Bio assay method)}

Set up five experiments in petridishes lined with filter paper circles, with 50 seeds per dish. The filter paper in the control is soaked with water ethanol (99:1). The other four are soaked respectively with the solutions of juglone, hydroquinone, arbutine and carvone containing $4 \mathrm{mg} / \mathrm{mi}$ water- ethanol (99:1) Incubate at $26^{\circ} \mathrm{C}$ for $24-$ $48 \mathrm{~h}$ in the light. Remove dishes and count number of seeds which have germinated. From these results and those of the control, it is possible to place the four compounds in order according to their effectiveness as inhibitors (Sivaraj et al., 2018).

\section{Gas chromatography-Mass Spectrometry (GC-MS)}

The methanol extract of selected samples were injected into a HP-5 column ( $30 \mathrm{~m} \mathrm{X} 0.25 \mathrm{~mm}$ i.d with $0.25 \mu \mathrm{m}$ film thickness), Agilent technologies 6890 N JEOL GC Mate II GC-MS model. Following chromatographic conditions were used: Helium as carrier gas, flow rate of $1 \mathrm{~mL} / \mathrm{min}$; and the injector was operated at $200{ }^{\circ} \mathrm{C}$ and column oven temperature was programmed as 50 $250{ }^{\circ} \mathrm{C}$ at a rate of $10{ }^{\circ} \mathrm{C} / \mathrm{min}$ injection mode. Following MS conditions were used: ionization voltage of $70 \mathrm{eV}$; ion source temperature of $250{ }^{\circ} \mathrm{C}$; interface temperature of $250{ }^{\circ} \mathrm{C}$; mass range of $50-600$ mass units. This studies carried out at Sargam Metal Private Limited, Thiruvanmiyur, Chennai-42.

\section{Identification of components}

The database of National Institute Standard and Technology (NIST) having more than 62,000 patterns was used for the interpretation on mass spectrum of GCMS. The mass spectrum of the unknown component was compared with the spectrum of the known components stored in the NIST library (Sivaraj et al., 2018).

\section{Antimicrobial Studies}

\section{Media preparation}

Bacterial media (Muller Hindon Media): $36 \mathrm{~g}$ of Muller Hindon Media (Hi-Media) was mixed with distilled water and then sterilized in autoclave at 
$15 \mathrm{Lb}$ pressure for 15 minutes. The sterilized media were poured in to Petri dishes. The solidified plates were bored with $5 \mathrm{~mm}$ diameter cork borer. The plate wells were used for the antibacterial studies.

Fungal media (PDA): $200 \mathrm{~g}$ of potato slices were boiled with distilled water. The potato infusion was used as water source of media preparation. $20 \mathrm{~g}$ of dextrose was mixed with potato infusion. $20 \mathrm{~g}$ of agar was added as a solidifying agent. These constituents were mixed and autoclaved. The solidifying plates were bored with $6 \mathrm{~mm}$ diameter cork borer.

\section{Antibacterial activity of the plant extract}

The methanolic extract of Hygrophila auriculata was used throughout the study. 25, 50 and $100 \mu 1$ of the extract were tested against different bacterial pathogens such as Escherichia coli, Citrobacter divergens, Enterobacter faecalis, Klebsiella pnemoniae and Serratia marcescens.

\section{Antifungal activity of the plant extract}

The methanolic extract of Hygrophila auriculata was used throughout the study. 25, 50 and $100 \mu \mathrm{l}$ of the extract were tested against different fungal pathogens, such as Aspergillus niger, Aspergillus flavus, Aspergillus fumigatous, Mucor indicus and Fusarium species.

\section{Well diffusion method}

Antibacterial and antifungal activity of the plant extract were tested using well diffusion method (Bauer et al., 1996). The prepared culture plates were inoculated with different selected strains of bacteria and fungi using streak plate method. Wells were made on the agar surface with $6 \mathrm{~mm}$ cork borer. The extracts were poured into the well using sterile syringe. The plates were incubated at $37 \pm 2{ }^{\circ} \mathrm{C}$ for $24 \mathrm{~h}$ for bacterial and $25 \pm 2{ }^{\circ} \mathrm{C}$ for $48 \mathrm{~h}$ for fungal activity. The plates were observed for the zone formation around the wells (Bauer et al., 1996).

The extract of the dried leaves was used throughout the study. The methanolic extract was dissolved in sterile distilled water to form dilution such as 25,50, and 100. Each concentration of the extracts was tested against different bacterial pathogens. It was demonstrated by well diffusion assay (Bauer et al., 1996). The zone of inhibition was calculated by measuring the diameter of the inhibition zone around the well (in $\mathrm{mm}$ ) including the well diameter. The readings were taken in three different fixed directions in all three replicates and the average values were tabulated (Bauer et al., 1996).

\section{Results and discussion}

For all human ailments, herbal medicines are available in our environment itself. The present investigation had been undertaken to find out the screening of the availability of phytochemicals and antimicrobial activity of methanol extract of entire plants of Hygrophila auriculata Schumach.

\section{Phytochemical studies}

Alkaloids, flavonoid, tannin and saponins were qualitatively evaluated in the methanolic extracts of Hygrophila auriculata Schumach. All the above substances were found to be present in this extract (Table 1).

\section{GC-MS analysis}

The results of GC-MS analysis screened the 20 compounds from the methanolic extract of leaves (Table 2). The methanolic leaf extract of the herb, Hygrophila auriculata was screened for antimicrobial activity against different pathogenic prokaryotic and eukaryotic microorganism in terms of zone inhibition.

The leaf extract showed inhibition against Aspergillus niger, but did not inhibit the other pathogenic fungi tested- Aspergillus flavus, Aspergillus fumigatous, Mucor indicus and Fusarium sp. (Table 3). Similar results are found in the literature. They have screened 7 medicinal plants including Hygrophila auriculata against 4 fungal strains (Ameer et al., 2007). Their results show that the leaf extract of Hygrophila auriculata shows antifungal activity against the fungal strains, Mucor mucedo and Aspergillus niger and is inactive against Aspergillus tamarii of Rhizopus solani. They have also shown that the seed extract of the plant inhibits all the above four fungi. In the present work, the leaf-extract 
alone was tested and the results are consistent with those found in earlier literature. The methanolic extract of entire plant was also screened against Gram +ve and Gram -ve bacterial strains and inhibition of bacterial growth was observed in the case of E. coli and Klebsiella pneumoniae; whereas there was no apparent antibacterial activity by thisextract against Citrobactor divergens, Enterobactor faecalis and Serratia marcescens (Table 4).

Table 1. Qualitative phytochemical screening of Hygrophila auriculata.

\begin{tabular}{|c|c|c|}
\hline \multirow{2}{*}{ Name of the compounds } & \multirow{2}{*}{ Name of the test } & Status of the substance \\
\hline & & Methanol extract \\
\hline \multirow[t]{2}{*}{ Carbohydrates } & a. Fehling's & + \\
\hline & b. Benedicts & + \\
\hline \multirow{4}{*}{ Alkaloids } & a. Mayer's & +++ \\
\hline & b. Hager's & ++ \\
\hline & c. Wagner's & ++ \\
\hline & d. Dragen Dorfff's & +++ \\
\hline \multirow{5}{*}{$\begin{array}{l}\text { Steroids } \\
\text { Tannin and phenols }\end{array}$} & Chloroform + acetic acid $+\quad \mathrm{H}_{2} \mathrm{SO}_{4}$ & + \\
\hline & a. $10 \%$ Lead acetate & - \\
\hline & b. $5 \%$ Ferric chloride & - \\
\hline & c. $1 \%$ gelatin & + \\
\hline & d. $10 \%$ Sodium chloride & - \\
\hline Saponins & Foam test & + \\
\hline Fixed oils and fats & Spot test & + \\
\hline Gums and mucilage & Alcoholic precipitation & - \\
\hline Proteins & Biuret test & +++ \\
\hline Flavonoids & $\mathrm{NaOH} / \mathrm{HCl}$ & ++ \\
\hline Volatile oils & Hydro distillation method & - \\
\hline Lipids & Harbone's test & + \\
\hline Reducing sugars & Miller's test & + \\
\hline Terpenoids & Salkowski test & ++ \\
\hline Quinines & Bioassay method & - \\
\hline
\end{tabular}

++++ = Rich amount; +++ = Moderate amount; ++ = Minimum amount; + = Present; - = Absent.

Table 2: GC-MS analysis revealed the presence of phytochemical component in leaf of Hygrophila auriculata.

\begin{tabular}{llllll}
\hline Peak & R. time & Area \% & Name of the compound(s) & Mol. formula & Mol. weight \\
\hline 1 & 5.818 & 8.23 & Butane, 1, 1- diethoxy- 3-methyl- & $\mathrm{C}_{9} \mathrm{H}_{20} \mathrm{O}_{2}$ & 160 \\
2 & 5.849 & 7.51 & Pentane,1,1-diethoxy- & $\mathrm{C}_{9} \mathrm{H}_{20} \mathrm{O}_{2}$ & 160 \\
3 & 6.032 & 0.50 & 3,3 -Diethoxy-2-Butanone & $\mathrm{C}_{8} \mathrm{H}_{16} \mathrm{O}_{3}$ & 160 \\
4 & 7.851 & 23.59 & Propane,1,1,3-triethoxy- & $\mathrm{C}_{9} \mathrm{H}_{20} \mathrm{O}_{3}$ & 176 \\
5 & 8.284 & 1.29 & 1,1,3- Triethoxybutane & $\mathrm{C}_{10} \mathrm{H}_{22} \mathrm{O}_{3}$ & 190 \\
6 & 10.395 & 0.68 & Benzene, [Ethoxy(1-Propenyloxy & $\mathrm{C}_{12} \mathrm{H}_{16} \mathrm{O}_{2}$ & 192 \\
7 & 12.788 & 0.67 & Nonane, 3,7-Dimethyl- & $\mathrm{C}_{11} \mathrm{H}_{24}$ & 156 \\
8 & 15.591 & 1.03 & Diethyl Phthalate & $\mathrm{C}_{12} \mathrm{H}_{14} \mathrm{O}_{4}$ & 222 \\
9 & 17.725 & 0.68 & Octadecanoic acid, 2-oxo- methyl ester & $\mathrm{C}_{19} \mathrm{H}_{36} \mathrm{O}_{3}$ & 312 \\
10 & 18.097 & 1.57 & Isopropyl myristate & $\mathrm{C}_{17} \mathrm{H}_{34} \mathrm{O}_{2}$ & 270 \\
11 & 18.267 & 11.37 & 2- Hexadecan-1-ol, 3,7,11,15-tetram & $\mathrm{C}_{20} \mathrm{H}_{40} \mathrm{O}$ & 296 \\
12 & 18.333 & 1.37 & 2,6,10-trimethyl, 14- Ethylene- 14-Pe & $\mathrm{C}_{12} \mathrm{H}_{24}$ & 168 \\
13 & 18.539 & 2.28 & 2,6,10- trimethyl, 14-Ethylene-14-Pe & $\mathrm{C}_{20} \mathrm{H}_{38}$ & 278 \\
14 & 18.746 & 3.60 & 7-Octadecyne,2-methyl- & $\mathrm{C}_{19} \mathrm{H}_{36}$ & 264 \\
15 & 19.915 & 1.49 & Heptadecanoic acid, Ethyl ester & $\mathrm{C}_{19} \mathrm{H}_{38} \mathrm{O}_{2}$ & 298 \\
16 & 21.227 & 22.65 & Phytol Isomer & $\mathrm{C}_{20} \mathrm{H}_{40} \mathrm{O}$ & 296 \\
17 & 22.402 & 1.10 & Phytol,acetat & $\mathrm{C}_{22} \mathrm{H}_{42} \mathrm{O}_{2}$ & 338 \\
18 & 24.901 & 2.72 & Tridecanol, 2-ethyl-2-methyl- & $\mathrm{C}_{16} \mathrm{H}_{34} \mathrm{O}$ & 242 \\
19 & 26.752 & 5.46 & Squalene & $\mathrm{C}_{30} \mathrm{H}_{50}$ & 410 \\
20 & 28.808 & 2.21 & 1,2-Benzenedicarboxylic & $\mathrm{C}_{24} \mathrm{H}_{38} \mathrm{O}_{4}$ & 390 \\
\hline
\end{tabular}


Table 3. Antifungal activity of methanolic extract of Hygrophila auriculata.

\begin{tabular}{lccc}
\hline Name of the fungi & \multicolumn{2}{c}{ Zone of inhibition (mm) } \\
\hline Aspergillus niger & $\mathbf{2 5} \boldsymbol{\mathbf { l }}$ & $\mathbf{5 0} \boldsymbol{\mathbf { l }}$ & $\mathbf{1 0 0} \boldsymbol{\mu l}$ \\
Aspergillus flavus & - & - & 10 \\
Aspergillus fumigatus & - & - & - \\
Mucor indicus & - & - & - \\
Fusarium sp. & - & - & - \\
\hline
\end{tabular}

Table 4. Antibacterial activity of Hygrophilla auriculata.

\begin{tabular}{llll}
\hline Name of the bacteria & Zone of inhibition $(\mathbf{m m})$ & & $\mathbf{1 0 0} \boldsymbol{\mu l}$ \\
\cline { 2 - 4 } & $\mathbf{2 5} \boldsymbol{\mu l}$ & $\mathbf{5 0} \mathbf{l}$ & 12 \\
\hline Escherichia coli & 08 & - & - \\
Citrobacter divergens & - & - & - \\
Enterobacter faecalis & - & 11 & 16 \\
Klebsiella pneumoniae & 09 & - & - \\
Serratia marcescens & - & & \\
\hline
\end{tabular}

The antifungal activity of plant extract have been attributed mainly to bioactive protein/peptide. Herbs are staging a comeback and a herbal renaissance is blooming across the world. They have been prized for their medicinal, flavouring and aromatic qualities for centuries and yet for a while they were over shadowed by the synthetic products of the modern civilization. But once having realized their serious side effects, people are going back to nature with hopes of safety and security. Today, herbs are finding diverse uses in the society from medicine to manure insecticides, pesticides and many articles of daily uses.

\section{Conclusions}

In India medicinal plants are unaccountable national treasure. Recently, the many side effects of long term use of synthetic drugs created awareness among the people to switch over from synthetic medicine to naturally based traditional medicine. A laborious research work is required to evaluate the potentialities of herbal based medicine. It has been estimated that higher plants produce more than 100,000 secondary metabolites of which only $15-20 \%$ have been chemically characterized. As a preliminary step, in the present study, the medicinal plant Hygrophila auriculata Schumach was selected and the major phytochemicals were present in this plant were analysed using standard qualitative tests. The antimicrobial activity of the methanolic extract of the plant was studied against five selected bacterial and five selected fungal pathogens.

\section{Conflict of interest statement}

Authors declare that they have no conflict of interest.

\section{References}

Ameer, J., Muhammad Shahid, M., Masud-Ul-Haq, Muhammed Ashraf, 2007. Screening of some medicinal plants for isolation of antifungal proteins and peptides. Pak. J. Bot., 39: 211-221.

Bauer, A.W., Kirby, W.M., Truck, H., Shreeies, J.C., 1996. Antibiotic susceptibility testing by standardized single disc method. Am. J. Clin Pathol., 45(4): 493-496.

Chandrasekar, S.B., Bhanumathy, M., Pawar, A.T., Somasundaram, T., 2010. Phytopharmacology of Ficus religiosa. Pharmacogn. Rev., 4(8): 195-199.

Harborne, J.B., 1984. Phytochemical Methods: A Guide to Modern Techniques of Plant Analysis. $2^{\text {nd }}$ Edn., Chapman and Hall, Londan, p.288.

Jacobson, M.F., Silverglade, B., 1999. Functional foods: health boon or quackery? British Med. J., 319(24): 205-206.

Joshi, S.G., 2000. Medicinal Plants. Osford \& IBH publishing Co. Pvt. Ltd., New Delhi.

Kokate, C.K., Khandelwal, K.R., Pawar, A.P., Gohale, S.B., 1995. Practical Pharmacognosy, 3rd Edn., Nirali Prakashan, Pune, p. 137-139.

Kumar, R., 1998. Conservation and management of mangroves in India, with special reference to the state of Goa and the Middle Andaman Islands" Rajiv Kumar is a Divisional Forest Officer in the Indian Forest Service Rangat, Andaman and 
Nicobar Islands, India Andaman and Nicobar Islands Environment and Forest Department, 1997. Management Plan for Conservation of Mangrove and Nicobar Islands, p. 1-6.

Miller, L.G., 1998. Herbal Medicinals: Selected clinical considerations focusing on known or potential drugherb interactions. Arch. Int. Med., 158: 2200-2211.

Mukherjee, P.K., Maiti, K., Mukherjee, K., Houghton, P.J., 2006. Leads from Indian medicinal plants with hypoglycemic potentials. J. Ethnopharmacol., 106: $1-28$.

Patra, A., Murthy, P.N., Jha, S., Aher, V.D., Chattopadhyay, P., Panigrahi, G., Roy., 2009. Antiinflammatory and antipyretic activities of Hygrophila spinosa T. Anders leaves (Acanthaceae). Trop. J. Pharm. Res., 8(2): 133-137.

Singh, A., Handa, S.S., 1995. Hepatoprotective activity of Apium graveolens and Hygrophila auriculata against paracetamol and thioacetamide intoxication in rats. J. Ethnopharmacol., 49: 119-126.
Sivaraj, C., Nikhishaa Sree, R., Gayathri, P.K., Arumugam, P., 2018. Antioxidant activities and GC-MS analysis of essential oil extracted from Salvia officinalis L. 7(2): 1440-1444.

Sivarajan, V.V., 2017. Indra Balachandar, Ayurvedic drugs and their plant sources. Kerala.

Sofowora, E.A., 1984. Medicinal Plants and Traditions Medicine in Africa. Wiley, London, pp.178-182.

Taylor, J.L.S., Rabe, T., McGaw, L.J., Jager, A.K., Staden,V.J., 2001. Towards the scientific validation of traditional medicinal plants. Plant Growth Regul., 34(1): 23-37.

Shanmugasundaram, P., Venkataraman, S., 2005. Antinociceptive activity of Hygrophila auriculata (Schum) Heine. Afr. J. Trad. CAM., 2(1): 62-69.

Vijayakumar, M., Govindarajan, R., Rao, G.M.M., Rao, C.V., Shirwaikar, A., Mehrotra, S., Pushpangadan, P., 2006. Action of Hygrophila auriculata against streptozotocin-induced oxidative stress. J. Ethnopharmacol., 104(3), 356-361.

\section{How to cite this article:}

Suresh Kumar, J., Nirmala, R., Venkatraman, A., 2021. Phytochemical and antimicrobial studies on Hygrophila auriculata Schumach. Int. J. Curr. Res. Biosci. Plant Biol., 8(12): 23-31.

doi: https://doi.org/10.20546/ijcrbp.2021.812.004 